\title{
SOB O SIGNO DE EROS
}

\author{
Álvaro Cardoso Gomes*
}

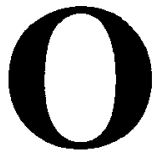

fenômeno da intertextualidade, ou seja, o diálogo de um escritor com outros escritores do passado, do presente (escritores pertencentes à literatura nacional ou estrangeira), o diálogo do escritor consigo próprio, num processo constante de autoreferenciação, talvez seja uma das marcas mais significativas da literatura contemporânea. É bem verdade que o fenômeno da intertextualidade é um procedimento inerente ou condição sine qua non do fazer literário, na medida em que todo escritor se inscreve dentro de uma tradição que reverencia ou rejeita, na medida em que, via de regra, dialoga com seus pares. Em outras palavras, escritor algum pode inventar do nada: sejam formas ou temas, é a tradição que sempre os fornece, e cada novo autor os atualiza, mesmo quando tem a intenção deliberada de, iconoclasticamente, destruir os modelos, como aconteceu, sobretudo, com as vanguardas. Contudo, se o fenômeno da intertextualidade sempre existiu em literatura, é na era contemporânea que irá se manifestar com mais intensidade; em outras palavras, "o mundo moderno parece fascinado pela capacidade que os nossos sistemas

* Professor titular aposentado da USP. Escritor e crítico literário, autor de, entre outras obras, A voz itinerante: o romance português contemporâneo, A estética simbolista, A santidade do alquimista: ensaios sobre Poe e Baudelaire, Os rios inumeráveis (romance), Contracanto (romance). 
humanos têm para se referir a si mesmos num processo incessante de reflexividade". 1

No tocante a esse processo de relação com a tradição, é preciso distinguir três posturas distintas: a) a das eras clássicas; b) a das eras românticas; c) a da modernidade. No primeiro caso, a relação com a tradição era sempre harmoniosa, pois os autores tinham por norma a imitação deliberada dos procedimentos artísticos dos escritores considerados modelares. Assim, um Camões, ao parafrasear o verso Arma virunque cano de Virgílio, em Os Lusíadas, seguia uma praxe determinada pelas retóricas de então, que era a de reverenciar um mestre, tanto na forma (a estrutura da epopéia), quanto no tema, tentando presentificar o que a tradição cunhou como um modelo de representação do mundo. Verifica-se idêntica intenção na adesão ao neoplatonismo, bebido de uma fonte que é a de Petrarca: em sonetos como "Transforma-se o amador na cousa amada", "Sete anos de pastor Jacó servia", "Alma minha gentil que te partiste”, entre outros, o procedimento da imitação, da paráfrase, está presente, não só na temática, como também na explícita apropriação de versos petrarqueanos ("L'amante nell'amatto si trasforma", "Questa anima gentil che si diparte", por exemplo). Portanto, verifica-se aí a consciência de modelos aprioristicamente concebidos que devem necessariamente orientar o discípulo a partir da lição de um mestre consagrado.

Com o advento do Romantismo e a eclosão do individualismo, essa prática, a imitação, passa a ser desprezada em prol do princípio da originalidade da criação artística. A rejeição das formas paródicas pelo Romantismo é atribuída a uma "ética capitalista emergente que fez da literatura uma mercadoria que podia ser possuída por um indivíduo". 2 Dessa perspectiva, o procedimento imitativo seria considerado desprezível porque parasitário. Não obstante isso, o fenômeno da intertextualidade continua a ser posto em prática entre os românticos, apesar da repugnância que a palavra "imitação" possa provocar. Esse movimento de autoreferenciação não se dá tanto na forma, na apropriação de estruturas modelares, como acontecia entre os clássicos, mas na glosa de temas, no uso da paródia, em seu sentido original de "contracanto"." Assim, por exemplo, quando poetas como Gonçalves Dias, Casimiro de Abreu,

1 HUTCHEON, Linda. Uma teoria da paródia. Lisboa: Edições 70, 1989. p. 11-12.

2 HUTCHEON, p. 15.

3 "O termo grego paródia implicava a idéia de uma canção que era cantada ao lado de outra, como uma espécie de contracanto." SANT'ANNA, Afonso Romano de. Paródia, paráfrase \& Cia. Sāo Paulo: Ática, 1991, p. 12. 
Álvares de Azevedo celebram as "primícias primaveris" em suas "canções do exílio", têm como referencial temático "A canção de Mignon", de Goethe ("Conheces o país onde florescem os limoeiros, / Em meio à folhagem escura ardem os pomos de ouro"), cantando o sentimento nativista, o amor das terras tropicais, quase intocadas pela civilização. Nesse caso, a apropriação do modelo dá-se tão só no plano ideativo, num canto que corre paralelo ao canto do poeta que inspirou os parodistas.

$\mathrm{Na}$ modernidade, o fenômeno da intertextualidade torna-se mais freqüente, tanto em intenção, quanto em quantidade, talvez devido ao fato de que a "escrita pós-moderna compartilha essa implícita crítica ideológica aos pressupostos que estão por detrás dos conceitos humanistas do século XIX a respeito do autor e do texto". 4 De modo deliberado, autores considerados modernos ou contemporâneos visitarão o passado (ou mesmo o presente), com vistas a estabelecer um diálogo crítico com seus comparsas. Verifica-se assim um distanciamento do autor em relação a um modelo, "uma repetição alargada com diferença crítica", provocada talvez por uma perda da fé na imutabilidade de valores, que teve início nos fins do século XVIII com a revolução romântica. Quanto ao fenômeno da quantidade, observa-se a intensificação do processo da intertextualidade na era contemporânea, a ponto de chamar a atenção da crítica que elabora, a partir daí, a concepção da estética do pós-modernismo, fundada principalmente na recorrência paródica. Talvez isso se deva ao fato de, na modernidade, a invenção ter-se esgotado, como observa Frederic Jameson: "num mundo em que a inovação estilística já não é possível, só resta imitar os estilos mortos, falar através de máscaras e com as vozes e estilos do museu imaginário". 5 A diferença da utilização da paródia na modernidade, em relação à utilização desta figura nas eras clássica e romântica, reside, portanto, no seguinte: se comparamos a postura do escritor clássico com a do pós-moderno, notamos que este não pratica a reverência pura e simples a um modelo, pois seu distanciamento crítico, irônico, evita que isso se realize em plenitude. No que diz respeito ao escritor do Romantismo, o autor pós-moderno, pondo em xeque o princípio da originalidade, de autenticidade romântica, revisita com liberdade os textos consagrados, como se a produção literária fosse um efeito de linguagem, ou ainda, como se o autor fosse possuído por linguagens que falam por ele. A prática da escrita, dentro da modernidade, caracteriza-se pela espontânea

4 HUTCHEON, p. 169.

5 JAMESON, Frederic. O pós-modernismo e a sociedade de consumo. In: KAPLAN, E. Ann (Org.). O mal-estar no pos-modernismo. Rio de Janeiro: Zahar, 1993. p. 31. 
manipulação de textos que pertençam, de modo geral, à humanidade. $\mathrm{O}$ autor, perdendo a aura de iluminado pelos deuses, ou musas, ou por uma voz interior, não é senão um "organizador" de uma matéria que a realidade lhe oferece. Seu trabalho, nos casos mais extremos, traduz-se simplesmente pela arrumação, pela reordenação de um corpus que ele colhe sem cerimônia no passado ou em seu próprio tempo. A marca da individualidade do autor pós-moderno, em muitos casos, se revelará obliquamente, através do distanciamento crítico, através de uma postura irônica.

O propósito deste nosso ensaio é estudar o fenômeno da intertextualidade, tendo por base a obra romanesca de Almeida Faria, um dos mais importantes escritores portugueses contemporâneos. O autor de $A$ paixão talvez seja, na literatura portuguesa da atualidade, o romancista que mais trabalha com este diálogo constante com escritores tanto portugueses quanto universais. A esse respeito, o crítico Álvaro Manuel Machado comenta o seguinte: "Almeida Faria [...] cultiva um sempre renovado experimentalismo em que predomina a intertextualidade, sobretudo no sentido da 'anxiety of influence', dado por Harold Bloom em ensaio comparativo exemplar". ${ }^{6}$ Em sua obra, Almeida Faria utilizase da intertextualidade, adotando três posturas fundamentais. Num primeiro caso, reverencia escritores e/ou textos da tradição e da modernidade - desta maneira, seu texto torna-se o espaço privilegiado onde o passado literário se torna presente ou se reatualiza. Num segundo caso, critica ironicamente escritores e/ou textos representativos de uma tradição passadista. Num terceiro caso, serve-se de escritores que reverencia para promover críticas à situação de seu país. Essas três posturas aparecem disseminadas por sua obra, que compreende seis romances (Rumor branco, Tetralogia lusitana: A paixão, Cortes, Lusitânia, Cavaleiro andante, $O$ conquistador) ${ }^{7}$ e insere-se de maneira evidente no que vem se convencionando chamar de "escrita pós-moderna", devido ao fenômeno da "estilização", da "carnavalização", da "intextualidade". Em Almeida Faria, de maneira deliberada, acontece o fenômeno da apropriação da matéria alheia, através da citação, da epígrafe, da paráfrase e da paródia.

Pretendemos examinar as recorrências intertextuais em Almeida Faria, concentrando-nos, de maneira fundamental, na análise da Tetralogia lusitana e, secundariamente, de $O$ conquistador. Numa primeira instância, é nosso

6 MACHADO, Álvaro Manuel. A novelistica contemporanea. Lisboa: Bertrand, 1984. p. $16-17$.

7 No transcorrer do trabalho, esses romances são representados, nas notas, pelas seguintes siglas: A paixão (P), Cortes (C), Lusitania (L), Cavaleiro andante (CA), O conquistador (CO). 
propósito trabalhar com alguns conceitos teóricos, principalmente os que dizem respeito à paródia; numa segunda instância, procuraremos mostrar como e por que Almeida Faria se utiliza de maneira tão ostensiva da paródia e, numa terceira instância, quais são os mitos glosados preferencialmente pelo autor. Suas personagens, como que tomadas por arquétipos universais e/ou nacionais, revivem de modo paródico alguns mitos fundamentais da história universal e de sua pátria, principalmente os da paixão de Cristo e os da aventura guerreira ou da expansão colonial.

Partindo-se do mais simples para o mais complexo, é possível distinguir basicamente quatro tipos de diálogo intertextual: a epígrafe, a citação, a paráfrase e a paródia. A epígrafe - "fragmentos de textos que servem de lema ou divisa de uma obra, capítulo ou poema"8 -, geralmente entre aspas, às vezes abre um romance ou aparece abrindo capítulos de modo destacado. São três os romances de Almeida Faria que se utilizam desse recurso: Lusitânia, Cavaleiro andante e $O$ conquistador. O primeiro deles, que tem como base a Revolução dos Cravos, abre com uma citação de Eça de Queirós, de 1880: “- Pátria para sempre passada, memória quase perdida!”. O tom da epígrafe, de caráter finissecular, expressando o princípio do "derrotismo" da geração de 70, especialmente em sua vertente de "Os vencidos da vida", de certa maneira, explicará a desilusão vivida pelas personagens do romance com o processo revolucionário. Em Cavaleiro andante, Almeida Faria inscreve na abertura do livro duas epígrafes, uma de Hegel: "O Cavaleiro andante que quer defender a viúva e o órfão não tem hoje lugar: são agora a polícia, os tribunais, o exército, o governo que tomaram o lugar dos objetivos quiméricos, perseguidos pelos cavaleiros", outra, de Antero de Quental: "Sonho que sou um Cavaleiro andante../Por desertos, por sóis, por noite escura./Paladino do amor, busco anelante/O palácio encantado da Ventura!" O motivo do Cavaleiro andante é recorrente na obra e será representado pelas personagens João Carlos e André, somente que de perspectiva paródica. Ambos buscam ideais quiméricos, de que não têm consciência exata, e seus palafréns são representados pelos boeings que atravessam os ares. Esta obra tem como base o motivo da procura, sugerida pela epígrafe de Antero de Quental e, ao mesmo tempo, trata do esvaziamento dessa mesma procura, corroborando as palavras de Hegel.

8 MOISÉS, Massaud. Dicionário de termos literários. 3. ed. São Paulo: Cultrix, 1983. p. 189. 
Ainda quanto à epígrafe, verifica-se que $O$ conquistador é o romance de Almeida Faria que mais se utiliza deste recurso: todos os sete capítulos do livro são antecedidos de frases alheias, que funcionam como verdadeiros motes ou Leitmotiven. Ao mesmo tempo, porém, tais epígrafes como que representam um diálogo que o autor estabelece com escritores que talvez façam parte de seu repertório de leitura. As epígrafes são as seguintes: Vergilius, "si vera est fama"; Daniel Defoe, "in speech an irony, in fact a fiction"; Camilo José Cela, "el número siete, hijo mío, es un número muy importante, ya lo verás"; Isak Dinesen, "madame, to my mind there never was a great artist who was not a bit of charlatan; nor a great king, nor a god"; Giorgio Manganelli, "lo sai, dunque, che questa è la descrizione del nostro amore, che io lo non sai mai dove sei tu, e tu non sai mais dove sono io"; Diderot, "Il y a peu des relations auxquelles on ne puisse appliquer ce que Strabon disait de celle de Ménélas: je vois bien que tout homme qui écrit ses voyages est un menteur"; Cervantes, "su libro tiene algo de buena invención, propone algo, y no concluye nada: es menester esperar la segunda parte que promete: quizá com la enmienda alcanzará del todo la misericordia que ahora se le niega..." De maneira geral, pelo menos, quatro epígrafes deste livro remetem para a questão da mistificação literária, da relação entre ficção e realidade. Almeida Faria, desse modo, ironicamente, acentua o clima ambíguo de todo o romance, que oscila entre o relato lendário, mítico, a biografia e o romance de aprendizagem. Quanto às demais epígrafes, uma trata do número sete (que é a conta de todos os capítulos) e que é comentado esotericamente pela própria personagem no capítulo, a outra trata da questão amorosa, também basilar no livro, e a última sugere que a obra terá uma continuação.

A citação, próxima da epígrafe, remete ao autor glosado de forma explícita, podendo vir entre aspas ou incorporada ao texto do glosador, como, por exemplo, em Cavaleiro andante, quando a personagem Marta cita estes versos: "Não retornam/os antigos dias, sei-o, cada abril/vermelho, de juventude, é passado" (p. 110). A citação vem a propósito de um comentário que a personagem faz a respeito da atividade revolucionária extremista. $O$ poema de Pasolini citado é "epitáfio" para o "caminho bombista, o mais mesquinho, abjecto e vil" e para a "revolução de abril". Outro exemplo de citação, somente que agora sem aspas, à p. 87 do mesmo romance, dispõe a letra de uma literatura de cordel referente a procedimentos a adotar na macumba, de que registramos aqui um excerto: "Tem de botar na macumba/uma figa e dois anéis/um galho de pinhão roxo/um dobrão de vinte réis/duas pontas de charutos/para curar em dez minutos/macumba que não deu certo./Etc., etc,". Casos de incorporação da citação dos autores glosados ao texto de Almeida Faria, portanto, sem a 
utilização das aspas, são freqüentes, como acontece com os poetas Byron e Rilke ( $L$, p. 111 e $C A$, p. 150). O que diferencia o texto do original e o da "cópia" é a língua utilizada (o inglês e o alemão). Mas é preciso considerar também que, no caso de Rilke, a fronteira entre a mera citação e a paródia pode residir na substituição de um nome do texto original do poeta alemão: "aber Marta! Wir kommen zu spät". Marta é a nova Eurídice na imaginação de J. C. que assim, ironicamente, altera ligeiramente o poema rilkeano.

A paráfrase, por sua vez, é caracterizada pela "fidelidade ao modelo original", estando, portanto, "ao lado da imitação, da cópia". " A paráfrase comparece em Almeida Faria quando ele não fornece ao leitor as pistas de identificação do modelo e "copia" o autor que lhe serviu de ponto de partida, integrando-o naturalmente ao texto que criou. Como por exemplo neste fragmento: "merda para esta vida suspensa dos depois ou, como dizia o Gordo, adiada na tristeza de nunca sermos dois" ( $C A$, p. 91). Há, neste caso, um verso de um poeta deslocado do seu contexto e apresentado sem aspas (e integrado) no novo contexto do romance do autor, como se dele fizesse parte natural. A descoberta de que o fragmento pertence ao poema "Partida" de Sá-Carneiro pode advir do conhecimento específico que o leitor tem da poesia portuguesa moderna ou ainda da pista que Almeida Faria nos fornece, quando a personagem Sônia remete a autoria do fragmento ao "Gordo". A sinédoque "gordo" serve para auxiliar na identificação do texto que serviu para complementar o raciocínio da personagem, na medida em que é uma referência a um dado biográfico, mais propriamente ao complexo que Sá-Carneiro tinha por ser gordo, expresso no poema autodepreciativo "Aqueloutro": "o mago sem condão, o Esfinge Gorda...". Contudo, se considerarmos que o princípio inerente ao trabalho com a paráfrase é a fidelidade de um texto a outro, o problema aqui se complica, porquanto a fidelidade de Almeida Faria a Sá-Carneiro é relativa. Parece que o novo contexto integra o texto original numa nova realidade, modificando seu sentido e fazendo que o comportamento parafrásico, que se pauta pela seme-lhança entre textos, se aproxime do paródico, que se pauta pela diferença. O irreverente substantivo "merda", utilizado no início do parágrafo, atenua o tom solene e nada revoltoso com que Sá-Carneiro se manifesta. Almeida Faria serve-se de Sá-Carneiro, citando-o, para transfigurar uma situação de raiva, de impotência por parte de Sônia, que não se conforma por não poder ficar com André: "imaginas a melancolia de não te ter comigo". 
A paródia representa a intensificação de um processo de estilização em relação à paráfrase. Enquanto esta se apóia no efeito da continuidade ou na intertextualidade das semelhanças, aquela se apóia no efeito da descontinuidade ou na intertextualidade das diferenças. ${ }^{10}$ A paródia, de acordo com a etimologia, uma "pára ode", "uma canção cantada ao lado da outra", implica um modelo que é submetido a uma operação transformadora de estrutura e, consequientemente, de sentido, ou seja, "repetição com distância crítica, que marca a diferença em vez da semelhança". "I Essa distância crítica é atingida pela utilização da figura da ironia que age sobre o princípio da duplicidade dos discursos ou pela deformação de um discurso em relação ao que lhe serve de modelo. O distanciamento irônico é que provoca a quebra com a tradição, com a idéia de continuidade e instaura uma nova ordem, daí resultando a intenção crítica que tem, como alvo, ora o próprio texto que serve de ponto de partida, ora o contexto, dentro do qual o modelo é reatualizado, ora ainda, em muitos casos, outros textos, em que o modelo serve de espelho ou contraponto.

É preciso esclarecer, contudo, que a paródia não deve ser entendida apenas como uma "imitação ridicularizadora", conforme é conceituada pelo senso comum e que, por isso mesmo, visa a destruir um modelo, deformando-o ou acentuando-lhe os aspectos grotescos. Nem sempre a paródia tem esse efeito dessacralizador de um modelo ou demolidor do passado, porquanto o simples fato de um escritor voltar-se para o passado ou para o modelo, em muitos casos, significa uma espécie de reverência em direção ao autor que lhe serviu de ponto de partida. ${ }^{12} \mathrm{~A}$ força da ironia, na paródia, provém da confrontação de discursos e "nem sempre às custas do texto parodiado". ${ }^{13}$ Muitas vezes, o texto que é o ponto de partida continua prestigiado pelo parodista, c o efeito irônico nasce da inserção do novo texto dentro de uma realidade que não mais o comporta.

Vem daí que, em muitos casos, o efeito crítico passe a se exercer sobre a realidade presente, auxiliado que é pela revisitação de um modelo do passado. Em suma, a paródia é paradoxal em sua essência, pois “parodiar é sacralizar o passado e questioná-lo ao mesmo tempo". ${ }^{14}$ Um exemplo dessa tendência em

10 SANT'ANNA, p. 28.

11 HUTCHEON, p. 17.

12 Sendo assim, afirmações como a de Frederic Jameson, a respeito do caráter ridicularizador da paródia devem ser apreciadas com bastante reserva: "a paródia põe em destaque a singularidade desses estilos e toma suas idiossincrasias e excentricidades para produzir uma imitação que zomba do original". JAMESON, p. 28.

13 HUTCHEON, p. 17.

14 HUTCHEON, p. 165. 
Almeida Faria é a incorporação que ele faz de fragmentos de textos de Camões. Ao glosar Os Lusiadas, sua intenção não é ridicularizar a epopéia seiscentista, mas sim promover, através da sua deformação, uma crítica da situação presente, como a mostrar que os feitos bélicos do passado, cantados de modo altissonante, não encontram mais guarida no presente, a não ser de forma grotesca. Um exemplo disso é a fala de J. C. fechando o capítulo 10 de Cavaleiro andante com a frase "contra mares há muito navegados", paródia evidente de "por mares nunca de antes navegados". Observe-se que o fenômeno parodístico, presente na deformação do verso camoneano ("contra" substitui "por" e "há muito", "nunca de antes"), serve para mostrar a impotência do homem do presente em relação ao ufanismo do conquistador do passado. Os mares, como representação do Desconhecido, no século XVI ofertavam-se como o Novo por conquistar. Já no presente, o encanto da aventura desaparece, e os mares representam apenas um obstáculo insuperável, contra o qual o novo nauta luta. Almeida Faria explicita aqui a síndrome vivida pelo homem do mundo contemporâneo, cujo sonho com as conquistas já morreu. Em outras palavras, esse sonho acaba se corporificando apenas como um poderoso mito.

Quanto ao mito, é possível dizer que ele possui várias acepções - a mais comum delas, decorrente da visão racionalista do século das Luzes e dos positivistas do século XIX, tinha um sentido claramente depreciativo: o de lenda, o de ficção, o de história fundamentada na superstição. Modernamente, depois de importantes estudos antropológicos, sobretudo os de Frazer, passou a ser concebido como uma história verdadeira, que fornece "modelos para o comportamento humano e, por isso mesmo, confere significado e valor à existência". ${ }^{15}$ Assim concebido, o mito conta histórias de entes sobrenaturais que viveram in illo tempore e que forneceram as leis básicas para a sobrevivência do homem aqui na Terra, como as referentes ao plantio, à caça, à pesca, etc. As histórias verdadeiras, nas civilizações primitivas, conservadas na memória de uma figura carismática da tribo, periodicamente, devem ser reatualizadas, não só através de narrativas, mas também através da dramatização dos eventos acontecidos abovo. Contar ou dramatizar é uma forma de fazer com que o tempo seja recuperado ou que se instaure novamente o tempo das origens, pleno de realizações.

Neste tipo de sociedade, a reflexividade ou este olhar para o passado é uma prática constante, como bem observa Giddens: "Há um sentido fundamen- 
tal em que a reflexividade é uma característica que define a ação humana. Todos os seres humanos se 'mantêm em contato' com os fundamentos daquilo que fazem como elemento essencial de o fazerem [...]. Nas culturas tradicionais, o passado é respeitado e os símbolos são valorizados porque contêm e perpetuam a experiência de gerações. A tradição é um modo de integrar o controle reflexivo da ação na organização espácio-temporal da comunidade". ${ }^{16} \mathrm{O}$ homem primitivo tem, pois, esse poder de neutralizar a passagem do tempo e, circularmente, retornar à perfeição inicial, que perpetua a "experiência de gerações", superando assim a cisão ontológica, provocada por um pecado ou uma falta. O pecado ou a falta são, em certas circunstâncias, representados pela perda da memória, pelo esquecimento das práticas tradicionais portadoras de sentido e emblematizadoras da união entre presente e passado. Como a tradição não é estática e tem de ser reinventada (Giddens), a posse da memória é fundamental, para que este processo de ruptura seja superado. A superação da cisão entre o homem e o mundo dá-se através das técnicas de "voltar atrás", mencionadas por Mircea Eliade e representadas, por exemplo, pelo regressus ad uterum, que consiste numa volta simbólica às origens. Esse ritual tem feições apocalípticas, ao visar à anulação do tempo: oblitera-se o presente para que o tempo $a b$ ovo retorne.

Com a modernidade, o homem passa a experimentar o tempo numa dimensão, digamos, horizontal. O tempo é cronológico, linear, escatológico e leva o homem a perder a capacidade de se integrar à tradição, ou ainda, a tradição esvazia-se $\mathfrak{e}$, por isso mesmo, torna-se incapaz de apontar caminhos para o presente; por conseguinte, não mais o ser humano se integra ao mundo. Aprofunda-se, pois, a crise ontológica, a cesura entre o homem e as coisas, devido ao racionalismo, que provoca o esquecimento das técnicas de "voltar atrás" e à descrença no poder reatualizante do mito. O resultado é a vivência agônica do tempo, a consciência de que este é irreversível, de que cada experiência é particularmente original e de que nem sempre é possível inseri-la dentro da tradição. E mesmo quando a tradição existe, ela só existe para ser transgredida. Ainda conforme Giddens, "sancionar uma prática por esta ser tradicional, não basta; a tradição pode ser justificada mas apenas à luz de um conhecimento que não ć, ele próprio, autenticado pela tradição" e "a rotinização da vida cotidiana não tem quaisquer relações intrínsecas com o passado, exceto na medida em que o que 'foi feito antes' coincide com o que pode ser defendido teoricamente à luz do conhecimento adquirido". 17 
Isto faz pensar que, embora a prática de retorno à tradição venha sendo, pelo menos no plano consciente, abandonada pelo homem moderno, ainda há resquícios do comportamento mítico na modernidade, seja no princípio da "coincidência", a que se refere Giddens, seja no princípio de resíduos inerentes ou no princípio de uma "herança genética" e/ou cultural que não se pode querer extirpar. Segundo Eliade, "alguns 'comportamentos míticos' ainda sobrevivem sob os nossos olhos. Não que se trate de 'sobrevivências' de uma mentalidade arcaica. Mas alguns aspectos e funções do pensamento mítico são constituintes do ser humano". ${ }^{18}$ Assim, ainda que o racionalismo impeça a entrega ingênua a rituais míticos, verifica-se que determinados arquétipos, ou imagens arcaicas de valor coletivo, continuam a impulsionar ou a orientar comportamentos do homem moderno. Todavia, ao invés de viver o mito em sua plenitude, ou seja, ao invés de vivê-lo numa dimensão capaz de reatualizar o passado na totalidade, o homem contemporâneo vive-o enquanto imitação degradada, ou seja, conscientemente ou não, ele parodia comportamentos míticos, tanto no plano dos atos quanto no da palavra. A paródia aqui é entendida, como demonstramos, nem sempre no sentido da ridicularização da tradição, mas no sentido de se mostrar que determinados comportamentos do passado, ainda que respeitados e so-nhados, não encontram guarida no presente. Em conseqüência, os parâmetros arquetípicos, presentes no inconsciente do homem moderno, quando vêm à luz, são mediados pela ironia, que provoca o distanciamento entre o ser e esses conteúdos míticos. A consciência, entre os primitivos, de que há fórmulas realmente eficazes de reatualizar o passado, é substituída, dentro da modernidade, por uma consciência que ora nega simplesmente ao passado a prerrogativa de ser fonte de inspiração ou de criação de modelos, que dêem sentido à existência, ora lança nostálgicos olhares para ele, tendo, porém, a certeza de que os procedimentos míticos não têm mais validade ou não mais se adequam à realidade do presente.

$\mathrm{Na}$ modernidade, a retomada de conteúdos míticos dá-se, sobretudo, em situações de crise e convulsões sociais. Já Carl Gustav Jung, em seus estudos sobre a psique humana, tratara do fenômeno da "inflação psíquica", que "envolve uma 'expansão da personalidade' além dos limites individuais". 19 Ao viver sob forte comoção, o homem vê-se invadido por imagens arcaicas, expressas simbolicamente através dos arquétipos. Ainda segundo Jung: "por

17 GIDDENS, p. 35.

18 ELIADE, Mircea. Mito e realidade. São Paulo: Perspectiva, 1970. p. 156.

19 JUNG, Carl Gustav. O eu e o inconsciente. Petrópolis: Vozes, 1979. p. 17. 
conseguinte, o indivíduo que incorporar a priori e inconscientemente a psique coletiva preexistente a seu próprio patrimônio ontogenético, como se a primeira fosse parte deste último, estenderá de modo ilegítimo os limites de sua personalidade, com as consequiências correspondentes". ${ }^{20}$ Nos casos das personagens de Almeida Faria, verifica-se uma dupla crise que as afeta, perturbando-lhes o equilíbrio psíquico: a crise familiar e a crise da nação. Com efeito, desde $A$ paixão até Cavaleiro andante, o que se vê, no plano do enredo, é a saga de uma família que se desintegra e cuja desintegração é o reflexo da desintegração da pátria. Ora, é neste momento crítico que vêm à tona não só imagens, mas também situações do passado universal ou nacional que constituem a base da explicação do presente ou a causa mesmo da crise em que os portugueses estão envolvidos. Acontece, portanto, a "inflação psíquica" - à sua revelia, as personagens passam a viver situações arcaicas e, por isso mesmo, a interpretar papéis de figuras míticas, que lhes indicam comportamentos a seguir e lhes determinam o caminho de uma penosa peregrinação. Contudo, como não mais vivem a idade da inocência, como são lúcidas, atormentadas por um racionalismo que as dilacera, que as afasta de si, que as afasta umas das outras e do meio em que vivem, experimentam um distanciamento irônico em relação a tais comportamentos e figuras, o que provoca verdadeira "carnavalização" dos mitos de sua história.

João Carlos e André talvez sejam as personagens de Almeida Faria em que melhor se observa o fenômeno da "inflação psíquica", quando sua personalidade individual é, por assim dizer, tomada simbolicamente por duas figuras míticas que podem ser desdobradas em figuras religiosas e profanas:

a) a do Messias:

- Jesus Cristo

b) a do Cavaleiro andante:

- Camões

- D. Sebastião

A figura de Jesus Cristo, no caso, tem um sentido mais universal; já as de Camões e D. Scbastião, embora estreitamente ligadas à de Cristo, têm um sentido mais restrito, na medida $\mathrm{em}$ que pertencem ao imaginário exclusivo do povo português.

A imagem de Jesus Cristo está ligada à tradição cristã e é revivida principalmente no primeiro romance da Tetralogia de Almeida Faria, A paixão. 
A justificativa para que o mito crístico, que tem caráter mais universal que o do cavaleiro andante, seja retomado com mais vigor no primeiro romance da série, fundamenta-se talvez no fato de que esta obra seja a abertura de um processo, ou ainda, que deflagre um processo apocalíptico que levará à quebra de uma tradição e, por conseguinte, ao início de penosa peregrinação. Contudo, é inegável que ambos os mitos são interligados e que é possível ver em Galaaz (o protótipo do Cavaleiro andante) um desdobramento de Jesus Cristo. Ainda é possível pensar também que Jesus Cristo, recuperado no momento agônico de sua história - o da paixão - será o fator decisivo de mudanças, de rupturas sonhadas, enquanto os cavaleiros realizarão na íntegra o mito da perda pela procura. Assim, é importante reafirmar que tais figuras míticas comparecerão sempre mediadas pela ironia, no momento em que Almeida Faria revisita, respectivamente, o Novo Testamento, textos camoneanos e glosas camoneanas (Os Lusiadas, canções de Camões e um soneto de Bocage) e recorrências sebastianistas, presentes na História, no imaginário popular e em textos de Bandarra, Vieira e Pessoa. A subversão empreendida pelo escritor português desses mitos supõe, ao cabo, uma organização triádica, uma dialética, compreendida por uma Tese (o fim dos tempos, com a morte e a ressurreição de Cristo), mormente em A paixão, uma Antítese (a esperança de um renascimento, com o sábado de Aleluia, o domingo de Páscoa, representado pela aurora da revolução), em Cortes, Lusitânia, Cavaleiro andante (mas já ressumando profundo desencanto) e uma Síntese, entrevista na substituição da prática guerreira pela prática amorosa, em Lusitânia, Cavaleiro andante, $O$ conquistador. A prevalência do signo de Eros, do princípio do prazer, em detrimento do princípio da realidade, este é o caminho que a trajetória das personagens parece apontar. Contudo, uma ressalva: em Almeida Faria, o princípio do prazer, que se oporá frontalmente à tradição guerreira e utilitarista do português, está diretamente ligado ao estético. Ou seja, a disponibilidade das personagens, que se entregam à ars amatoria (principalmente o Sebastião de $O$ conquistador), como que simbolicamente representa a disponibilidade do artista, que, segundo Baumgarten (citado pela personagem Marta), concebe o estético como um fim em si mesmo: "enquanto na lógica o elemento sensível é mero meio para chegar a um fim, na estética este elemento é um fim em si" ( $C A$, p. 122).

$\mathrm{O}$ início de todo o processo dialético dá-se, portanto, no primeiro romance da tetralogia, com a leitura paródica da paixão de Cristo. Esse romance chama a atenção sobretudo pela figura onipotente do pai, simulacro de senhor feudal. É esta figura que assombra e perturba as demais, impondo uma falsa unidade ao clã, através de sua pretensa força (que oculta sua extrema fraqueza). Rejeitado pelos filhos e pela mulher, odiado pelos trabalhadores, o velho 
Francisco será, mais adiante, morto pelos empregados da herdade, e sua morte passa, desse modo, a simbolizar o fim do tempo arcaico e o início dos novos tempos. Nota-se aqui uma primeira subversão do mito de Cristo: nos Evangelhos, o filho é sacrificado pelo pai, para que se possa, com este gesto extremado de amor pela humanidade, remir os homens com o sangue da vítima inocente, do cordeiro. Em A paixão, é o pai que é simbolicamente sacrificado, e, ao invés da idéia de remissão da humanidade, o que há é a sugestão de uma revolução. O filho João Carlos assume a máscara de um Cristo novo e subversivo, que, deixando a casa e perdendo-se no mundo, procurará romper o círculo da convenção e do conformismo.

Cristo comparece de modo paródico, a partir do instante em que Almeida Faria contamina o mito cristão com o mito pagão, como acontece no ritual iniciático de $A$ paixão, em que J.C. sacrifica um cordeiro: "na vila haverá vozes, altas e lamentosas dos animais que morrem; imolarei também, ele é, o nosso cordeiro, como as palavras mandam, sem a mancha, macho dum ano; agora vou matá-lo dentro da madrugada; um golpe brusco, grave, lhe abrirei a garganta, com a faca que gargantas abriu já antes deste, que sóis outros brilhou iguais ao de hoje, que outrora se cobriu do mesmo sangue" (p. 13). O ato da personagem abre, consagra a primavera, num ritual de nítido recorte pagão: o cordeiro substitui, simbolicamente, a vítima humana sacrificada à fertilidade da terra. Mircea Eliade observa em Tratado de história das religióes que "o ritual refaz a criação; nas plantas regenera-se por uma suspensão do tempo e pelo retorno ao momento inicial da plenitude cosmogônica. O corpo esquartejado da vítima coincide com o corpo do ser mítico primordial que deu vida às sementes pelo seu esquartejamento ritual". ${ }^{21}$ Como todo ritual mítico visa a reatualizar atos rcalizados no princípio dos tempos, instintivamente João Carlos repete os mesmos gestos de um homem inominado, obedecendo aos mandamentos das palavras, utilizando-se de uma faca já usada outrora. Ora, este ritual pagão, que impregna o cristão, dará nova face a este Cristo redivivo: o sangue derramado, similar ao sol (ou ao fogo que, no final do romance, purificará o gesto da personagem), representa também o ato de ruptura com a tradição, através da retomada da tradição. O sangue derramado da vítima inocente é o batismo iniciático do Cristo - mas, em sendo o ritual pagão (com o sangue e não com a água), o novo Cristo terá uma dimensão demoníaca, será na realidade um anti-Cristo, o homem subversivo que ressuscita, ou que resta do rescaldo do

21 ELIADE, Mircea. Tratado de historia das religiões. Lisboa: Cosmo, 1970. p. 411. 
velho mundo destruído pelo fogo: "só o homem ressuscita em cada dia, e o crucificado não é mais que um símbolo muito nítido para a morte e a ressurreição do próprio homem; haverá um lugar para os que ressuscitam, como houve aqui lugar para os que morrem" ( $P$, p. 159).

Esse velho tempo que será preciso destruir é representado por um Francisco ancorado no passado, dominado pela figura do próprio pai que o prendeu irremediavelmente ao mundo arcaico: "sempre também se soltou para o passado, nos amarrou à sombra que a ele o amarrara e nos incitou nunca a procurar; aconselhou-nos só a conservar, como compota, o que o avô ganhara" $(P$, p. 67). Impera no comportamento de Francisco a mesmice, a repetição de um ritual sempre idêntico, o ritual da usura, o que afeta a busca, na medida em que o prende avaramente aos bens acumulados de geração a geração. Ora, a busca, que, nos demais romances da Tetralogia, será a mola propulsora dos perdidos cavaleiros andantes J.C. e André, é essencial para a dimensão humana dos heróis romanescos. Conforme observa Lukács, "o espírito fundamental do romance, aquele que lhe determina a forma objetiva-se como psicologia dos heróis romanescos, esses heróis estão sempre em busca". ${ }^{22}$ Assim, cria-se a primeira grande oposição no romance entre o velho (o pai) e o novo (o filho): as velhas estruturas querem manter-se intactas, e os filhos, animados pelo sopro do novo, sonham em "escavar no ignorado" ( $C A$, p. 15). Nessa oposição, verifica-se que o mundo arcaico, além de seus estamentos ideológicos, é representado igualmente pelos valores palpáveis da terra, do dinheiro, da casa, ou da profissão, como se compreender a realidade implicasse compreendê-la da perspectiva dos bens de raiz. Já o mundo do novo nada oferece em termos de materialidade, pois a busca dos heróis aponta para o vazio, representado por sonhos indefinidos, pelo desejo de abraçar o oco do impossível.

Como o novo pretende substituir o velho, Francisco será afastado do palco das ações, ao morrer nas mãos vindicatórias dos campônios que buscam, dessa maneira equívoca, marcar seu espaço na História. Contudo, mesmo morto, o pai continua presente em todos os romances, dominando fantasmagoricamente os filhos, projetando-se neles, como bem observa Eduardo Lourenço: "O reino do Pai terminou - já terminara em Lusitânia, embora o seu hamletiano fantasma - fundador paire sobre todo o clã, num fascínio equívoco entre esquecimento desejado e memória ativa. No fundo, é ele ainda que condiciona o destino de André, o primogênito, o Filho, herdeiro mítico da ordem antiga subvertida." ${ }^{23}$ 
Essa onipresença do Pai será constante no inconsciente de J.C. - como se verá adiante, a recusa de gozar o prazer, a vida disponível junto a Marta, em Veneza, deve-se em parte ao senso de responsabilidade em manter a vida gregária do clã, que herdou de Francisco junto com André.

Outra oposição muito poderosa entre os dois mundos comparece nas imagens do fogo/sol/sangue, todas elas remetendo à sexualidade, à vida instintiva, à força, e o frio, ligado à esterilidade e à mortc. O primeiro conjunto de imagens comparece no referido capítulo inicial de $A$ paixão, em que J.C. sacrifica o cordeiro: o sangue derramado funde-se à chama do sol e ao calor ("um calor antigo me subirá dos braços para a boca e a boca saberá o cheiro do sangue"), e na revolta final da personagem que pretende destruir uma realidade para (re)construir o mundo: "ajudar com seus pulsos a construir o mundo, mundo outro que sonhara com a certeza que transcende a realidade, que sabia infalível, urgente, necessário, ainda que difícil, ainda que sangrento, mas era o sangue, sim, que viria sagrar, o sangue ressuscitava, doía, ardia, custava, mas destruía o passado como fogo, e erguia um futuro magnífico a partir da própria destruição, do próprio nada" ( $P$, p. 148). A imagem do frio aparece sobretudo nas reflexões de Marina: "o nosso mundo está frio e nenhum fogo o aquece" ( $P, \mathrm{p} .100)$. Esse mundo invernal contamina com sua esterilidade tudo que faz parte dele: mesmo as imagens do calor, do fogo têm o signo invertido, pois, ao invés de indiciarem a vida, a força, apontam para a morte. Isso fica bem patente quando Marina rememora o suicídio do bisavô: "na cama ensangüentada, tendo à direita da vista a bala e o seu buraco, e a arma ao lado, ainda quente, fumegando pólvora negra; a pólvora, esse fogo oculto, foco de fogo em potência" (ibidem). A onipresença do frio, que contamina inclusive o próprio fogo, serve para representar a esterilidade desse mundo que perdeu a vida: "viagem pelo espírito da mãe daquela casa, mãe estéril e mãe velha viajando pela casa, sem cio, sem carinho, sem nada" ( $P$, p. 142).

O novo é vivido por J.C., a reencarnação de Cristo, como já simbolicamente as iniciais do nome o indicam. Este assumir da imagem crística, aliás, vem sendo apontado por mais de um crítico, como Maria Alzira Seixo: "o cal vário de J. C. (João Carlos, a quem a insistência nas puras iniciais acentua o simbolismo religioso)" 24 e Cristina Robalo Cordeiro Oliveira: "o nascimento do tex to surge como o primeiro rito iniciático de uma sexta-feira santa em que

24 SEIXO, Maria Alzira. A palavra do romance. Lisboa: Horizonte, 1968. p. 195. 
o cordeiro pascal é imolado por João Carlos, personagem consagrada ao assumir a sua consciência em luta e a quem é concedida, por um batismo purificador, uma designação revolucionária e única, a de Jesus Cristo." ${ }^{25}$ A História Sagrada é retomada de modo parodístico: Almeida Faria compõe um discurso paralelo ao dos evangelistas que contaram a história de Cristo e compõe seu "contracanto", em que imagina o Cristo sem prerrogativas de divindade, revolucionário, vivendo num tempo de crise e revoltando-se contra o Pai tirânico, com sua intempestiva fuga de casa. A subversão do mito crístico evidencia-se sobretudo na relação conflitiva que se estabelece entre pai e filho. Se no Novo Testamento, Jesus Cristo, ainda que o lamente ("Pai, por que me abandonaste"), acaba por se conformar com seu destino de vítima inocente, no romance de Almeida Faria, dá-se precisamente o contrário. J.C. revolta-se contra a tirania do pai, que deseja sacrificá-lo a seus caprichos, impondo-lhe a vontade férrea, os valores que recebeu dos antepassados. Sua revolta implica que é ele quem sacrificará o genitor, abandonando-o e, ao mesmo tempo, abandonando o mundo de convenções da família prestes a desagregar-se. Dessa maneira, simbolicamente, o pai é que se transforma na vítima a ser sacrificada, o velho mundo que, na ressurreição do novo homem, cederá espaço ao tempo de redenção e esperança, como se pode ver no seguinte fragmento: "talvez que no sábado o homem ressuscite; porque não? só o homem ressuscita em cada dia e o crucificado não é mais que um símbolo muito nítido para a morte e ressurreição do próprio homem; haverá um lugar para os que ressuscitam, como houve aqui lugar para os que morrem; de fato, este é o livro dos mortos, dos mais mortos que os mortos, como o pai" (Sem grifo no original, p. 159).

Depois de romper com o pai, J.C. deixa o lar e parte para Lisboa. Possuído pela "tentação do demônio", como é peculiar nos heróis romanescos (no dizer de Lukács), inicia seu caminho com uma ruptura que será mais explícita em Cortes. Já o título do romance, bem como a epígrafe drummondiana - "tempo de gente cortada" - que fecha o livro, remetem para essa idéia de fissura. A separação de J.C. da família é similar à de Cristo, que se separa do pai putativo, a fim de que possa maturar. A respeito disso, Jung observa o seguinte: "Lembramos que, sem dúvida, a doutrina de Cristo queria separar o homem de sua família e que na conversação de Nicodemo vimos os esforços particulares do Cristo para dar à regressão um sentido simbólico. As duas

25 OLIVEIRA, Cristina Robalo Cordeiro. Almeida Faria: um itinerário. Colóquio/Letras, n. 69 , set. 1982 . p. 35 . 
tendências visam ao mesmo fim: liberar o homem de seu apego à família."26 Rompendo com o pai e assumindo a busca, mesmo a partir de um ato impensado, a personagem investe na procura do novo. Como um autêntico herói do "idealismo abstrato" de que fala Lukács, J. C. é movido pelos chamados "valores autênticos" que, confusamente, correm sua cabeça, sem, no entanto, terem um contorno definido: "ingressar inteiramente e sem cadeias noutra mentalidade, noutra classe, dedicar-se para sempre a um plano, a uma idéia, correr o perigo, aceitar o risco, o anonimato, a clandestinidade, sofrer se necessário, mas ajudar com os pulsos a construir o mundo" ( $P$, p. 148). À semelhança de Cristo, deixando o lar, a personagem sai pelo mundo a cumprir a sina a que se destinou. Contudo, como se viu, a idéia de ruptura drástica com o passado impregna o novo Messias de uma aura demoníaca, o que implica que ele vá, apocalipticamente, tentar destruir o velho. Instaura-se um caos original (que se identificará ao caos produzido pela revolução em Lusitânia) que substitui o cosmo envelhecido/envilecido. A idealidade é vazia, de maneira que o "ritual cristão" torna-se, parodisticamente, "de sacrifício mais do que salvação", no dizer de Maria Alzira Seixo. ${ }^{27}$

O conflito de J. C. com o pai é símbolo de um conflito mais amplo do que a simples demonstração de um confronto puramente familiar. Se se expandir o sentido dos romances de Almeida Faria, verifica-se que a saga das personagens emblematiza a do próprio Portugal e que, por conseguinte, a ruptura entre o pai e o filho emblematiza a ruptura entre o português e o país preso ao passado. A Revolução dos Cravos, que comparece em Lusitânia, é como que preludiada na pequena revolução de J.C. em casa. Assim, a paródia da História Sagrada parece estar a serviço da história profana, como se pode perceber na sequência romanesca. Depois da Paixão (A paixão), vêm o Sábado de Aleluia (Cortes) e a suposta redenção no Domingo Santo (Lusitânia), com a queda do regime ditatorial em 74. Manuel Gusmão, no prefácio da terceira edição de Cortes, apresenta este eixo metafórico que dá unidade à Tetralogia e funde o sagrado ao profano: "o modelo mítico da Paixão, oposição entre o mundo demoníaco da opressão totalitária e o claro mundo da redenção messiânica da liberdade demoníaca." Contudo, o leitor não se deve iludir com a idéia de que a Revolução de Abril (o mês, ellioticamente, mais cruel, como o autor ironicamente comenta) constitua o fim de um processo; em realidade, ela representará apenas um

26 JUNG, Carl Gustav. Métamorphoses de l'ame et ses symboles. Gêneve: Librairie de l'Université, 1967. p. 673.

27 SEIXO, p. 157. 
processo, um ritual de passagem. Com isto, configura-se mais como equívoca redenção, como se pode verificar no desencanto das personagens, sobretudo em Cavaleiro andante. A revolução, a par da benéfica demolição de arcaicas estruturas, criará um libertarismo de fachada, que não conseguirá, por exemplo, eliminar antigas crenças e superstições: "Será que se vão enfim realizar-se as profecias de Bandarra, que prometeu um Quinto Império a quem perdeu o seu? Será que um rei amado porque louco, incompetente e morto, em breve retornará, não para de novo nos lançar em perdidas batalhas, mas para nos salvar de todas as desgraças e ameaças de maiores males?"' $(C A$, p. 8-9). Para comprovar que as velhas estruturas ainda estão latentes, Almeida Faria trata da troca de favores entre a esquerda e a direita, como se as duas faces da ideologia acabassem por se assemelhar em seus propósitos quase idênticos. O libertarismo de fachada ainda está presente na linguagem, como se mostra admiravelmente no capítulo 17 de Cavaleiro andante, intitulado "Revolução e Linguagem", em que a liberdade é confundida com o à vontade de gritar obscenidades em público. Com isso, criticamente o autor mostra o desencanto nascido da frustração com o projeto revolucionário; contudo, esse desencanto é absolutamente necessário, em vista do fato de que a revolução, como todas as revoluções, depois de um breve instante de fulguração e conflito, tende a estagnar-se, criando uma estrutura de poder e de valores semelhantes em tudo à velha ordem que se tentou destruir. Eis aí por que tanto J.C. quanto André vivam, após a experiência rutilante dos primeiros tempos revolucionários, momentos de angústia, de desilusão quanto aos destinos da pátria.

Como já se disse, essas personagens e mais outras, como Sônia, Arminda, são heróis do "idealismo abstrato" e o sonho deles, por conseguinte, traduz-se por ser uma espécie de "idealidade vazia". Esta expressão cunhada por Hugo Friedrich, em Estrutura da lírica moderna, diz respeito aos conteúdos da poesia moderna, que não tem como determinação atingir um ideal plenamente identificado. ${ }^{28}$ De modo equivalente, as personagens de Almeida Faria não conseguem dar a seus sonhos um conteúdo definido e, por isso mesmo, parecem fadadas a viver uma aventura errante, sem que haja necessariamente um porto a que possam aportar. O próprio J.C., em carta a Marta, tem consciência desse esvaziamento do ideal, citando de modo sintomático um poeta que manifestou

28 "A meta da ascensão não só está distante, como vazia, uma idealidade sem conteúdo. Esta é um simples pólo de tensão, hiperbolicamente ambicionado, mas jamais atingido." FRIEDRICH, Hugo. Estrutura da lírica moderna. São Paulo: Duas Cidades, 1978. p. 48. 
como ninguém essa vivência tipicamente moderna da "idealidade vazia", o heterônimo pessoano, Álvaro de Campos: "Nós, de repente arrancados de nosso sono de séculos, podíamos sair da hibernação com alguma coletiva vontade, se ela existe. O mal é eu não a ver, e ao menos 'viajar ainda é viajar e o longe está sempre onde esteve - em parte nenhuma, graças a Deus!"' (CA, p. 47). Daí a diferença entre essas personagens e os heróis da tradição, movidos por ideais cristalizados numa crença ou em valores transcendentes. Talvez J.C. (e, em parte, André) sejam impulsionados pela busca irredutível do Novo, a que Baudelaire se refere no poema "Le Voyage": "os verdadeiros viajantes são aqueles que partem por partir" e que se manifesta em observações da personagem, como as seguintes: "Quem permanecer parado numa pátria, em sentido real ou figurado, talvez nunca chegue a nada. É preciso escavar no ignorado, lá onde o comum-de-muitos só se revela à vista do nômada sem tribo" e "A demanda do sonho milenário traz em si o melhor das revoluções, busca de um futuro futurante ou futurível. E se o futuro não existir, resta a paisagem variada, inédito espetáculo" ( $C A$, p. 47). O melhor das revoluções, não propriamente a revolução historicamente datada, mas aquela que se produz no espírito, está atrelado a um "futuro futurante", ou seja, um futuro sempre por haver, redundante em si mesmo e que não aponta para nenhuma saída específica, senão na própria procura de per si, como outra citação de versos de Álvaro de Campos faz acreditar: "fugas contínuas, idas, seja como for, seja para onde for, partir" (CA, p. 46).

Ora, esse deambular pelo espaço do "futuro futurante ou futurível" é que justifica o fato de J.C. e André transformarem-se em cavaleiros andantes paródicos, que investem na busca de um Graal inidentificável e que se perdem numa demanda profana ("desordenada demanda", diz J. C. em Cavaleiro andante, p. 158), cavalgando não mais corcéis, mas iniciáticos boeings, que mais se assemelham a Leviatãs engolidores de pobres Jonas. $\mathrm{O}$ fascínio que as novelas de cavalaria parecem exercer sobre Almeida Faria torna-se mais evidente no romance sintomaticamente intitulado Cavaleiro andante. Nesta obra, além do próprio título, as epígrafes de Hegel e Antero de Quental apontam para este tipo de narrativa, somente que com um sentido nostálgico/crítico. Para o filósofo alemão, o Cavaleiro andante hoje "não tem mais lugar", e seus "objetivos quiméricos" foram substituidos pela "polícia, os tribunais, o exército, o go-verno"; já o poeta português canta a desilusão do eu-poético que busca o "palácio da Ventura" e só encontra o vazio "e nada mais". Em conseqüência, a imagem do Cavaleiro andante percorre as páginas do romance, mas sempre de uma perspectiva paródica, de modo a ilustrar a impossibilidade de se viver o fabuloso, o ideal, "a demanda do sonho milenário". Galaaz, o mais puro dos 
cavaleiros, representado ora por J.C. ora por André, atravessa a obra na emblemática errância dessas duas personagens. Esta figura heróico-lendária também comparece nos sonhos de Marina e Jó. No caso da matriarca, como espécie de compensação para uma vida vazia, sem amor nem esperança. Expulsa do leito conjugal pelo marido, a mulher dorme sobre um tapete em que há a figuração desse ente mítico: "no velho tapete azul e vermelho com o cavaleiro levando à garupa do cavalo um alforje que julgo conter um tesouro e no arção dianteiro da sela uma jovem, namorada ou raptada, seminua e sobre cuja fuga eu sonhava, dormindo melhor que no leito conjugal" ( $C A$, p. 92). No caso de Jó, o menino revitaliza o mito pós-modernamente, fundindo-o com aventuras de heróis intergaláticos: "neste momento, vindos do Paço Aventuroso, chegam alguns cavaleiros com trajos de astronautas, à frente o claro Galaaz" $(C A$, p. 26). O Galaaz vestido com roupagens modernas, no inconsciente de Jó, é a representação simbólica de André aeronauta e que, ainda em sonhos, morre, subindo ao "Paço Aventuroso" ( $C A$, p. 178), contudo, sem ter acesso ao tão almejado Vaso. Essa fusão do arcaico com o moderno produz nova imagem do cavaleiro andante, um cavaleiro que erra sem destino e sem glória, à procura de um vaso sagrado que não existe: "é preciso partir à procura da chave que abrirá a cave onde se esconde e não se encontra o Graal" ( $C A$, p. 9).

Como autênticos cavaleiros andantes, vivendo um "rito de passagem", J. C. e André assumem aparentemente uma disponibilidade, própria de quem se entrega à aventura errante e, neste caso, vão simbolicamente se identificar com duas figuras históricas da tradição portuguesa, Camões e D. Sebastião que, de modos diferentes, celebram, para o imaginário português, o sonho da disponibilidade aventurosa, da conquista. Essas figuras que constituem um desdobramento de Jesus Cristo, porque simbolicamente sacrificadas, vivem num tempo de crise, quando se prenuncia a decadência do império luso e, ao mesmo tempo, vivem num intervalo entre a grandeza imaginada e a desgraça que as aguarda na morte sem glória e sem beleza. Camões projeta em Os Lusíadas o sonho de pujança de uma potência que, em realidade, é antífrase de um pais que vive "numa apagada e vil tristeza", por substituir os valores autênticos pelos inautênticos da ganância, da cobiça. Já D. Sebastião, levado pela loucura messiânica, almeja recuperar a glória perdida da nação c morre ingloriamente em Marrocos. A identificação entre essas figuras históricas e as personagens de Almeida Faria serve para reforçar o caráter parodístico de seu romance, pois J. C. vive sua "negativa epopéia" e André, da mesma idade do Encoberto, após doloroso périplo, irá morrer em África.

J. C. descobre sua vocação poética chegando em Lisboa e seu parâmetro às avessas, no inconsciente, é Camões, sobretudo, o épico, muitas vezes 
parodiado diretamente por ele e uma vez, pelo menos, parodiado por outrem. Os exemplos são muitos e todos apontam, via de regra, para o distanciamento irônico em relação ao modelo camoneano. Contudo, esse distanciamento irônico não elimina o respeito devido ao poeta, como se Almeida Faria ilustrasse a impossibilidade de se viver no século XX os sonhos de conquista do século XVI. Em Cavaleiro andante, J.C. comenta que sua peregrinação se dá "contra mares há muito navegados" ( $C A$, p. 34), ao passo que, em Os lusíadas, Camões diz que Vasco da Gama, o arquétipo do português conquistador, navegava "por mares nunca de antes navegados". Desse modo, enquanto, no poema épico, o herói parte para o desconhecido, que lhe abre as portas, devido à sua vontade férrea, devido à grandeza do sonho, no texto de Almeida Faria, o desconhecido torna-se conhecido, gasto por outros navegantes e, por isso mesmo, em vez de fornecer o estímulo à conquista, oferece-se como um obstáculo a ser transposto em troca de nada, visto que, depois dele, não há um porto, não há Índias. Neste mesmo romance, há uma fusão paródica de duas conhecidas canções camoneanas numa carta de Marta dirigida a J. C.: "Junto dos rios que vão para dentro do dia arrastando consigo os detritos da noite sobre os rios sem nome me encontrei, me perdi e procurei em vão ou não" (CA, p. 154). ${ }^{29}$ Observe-se a referência aos detritos do rio, ou seja, os restos de sonhos, conteúdos do inconsciente que continuam na vida em vigília. $O$ distanciamento do epicismo de Camões também acontece na oposição entre o verbo achar, utilizado pelo eu-poético do autor de $O s$ Lusíadas, e os verbos encontrar, perder-se e procurar, utilizados por Marta e que servem para marcar, de maneira bem nítida, sua desorientação.

Em Lusitânia, há outra referência importante a Camões quando J.C. parodia o episódio do Velho do Restelo, esvaziado de toda grandeza, ao contemplar os estragos feitos pelas autoridades em Cacilhas: "Andam estragando tudo, um dia até acabarão por pôr de parte essas arcaicas barcaças que, numa regata de vapores, certo não ganharão o primeiro prêmio, contudo conquistaram um lugar na mitologia da cidade. São o que nos resta das descobertas e viagens, do apregoado império e seus naufrágios, dos sublimes sucessos, dos desastres em má hora anunciados por um velho de venerando aspecto, que ficara entre as gentes no cais, postos em nós os olhos, meneando três vezes a cabeça, descontente, a voz pesada um pouco alevantando, que nós

29 "Junto de um seco, fero, estéril monte/inútil e despido" e "Sobre os rios que vão/por Babilônia me achei". 
no rio ouvimos claramente" (Sem grifo no original, p. 11-12). No texto camoneano, a passagem é a seguinte: "Mas um velho, de aspeito venerando,/Que ficava nas praias, entre a gente,/Postos em nós os olhos, meneando/Três vezes a cabeça, descontente,/A voz pesada um pouco alevantando,/Que nós no mar ouvimos claramente," (IV, 94). A transcrição do texto de Camões é quase que literal: Almeida Faria somente acrescenta o plural em "gente", o adjunto adverbial "no cais" e troca "mar" por "rio". A paródia é conseguida graças ao deslocamento da figura veneranda do século XVI para o $\mathrm{XX}$ e, sobretudo, ao deslocamento do objeto da crítica. Nos Lusíadas, o alvo de Camões era a cobiça dos aventureiros, o abandono da terra em nome da conquista, o que implicava uma visão futuritiva por parte do velho do Restelo; já em Lusitânia, o alvo de Almeida Faria é o passado grandioso da pátria de que restam tão-só vestígios. Ainda em Lusitânia, este aspecto paródico que acentua, por analogia, a degradação do passado em relação ao presente, comparece no seguinte fragmento relativo a um monólogo de Jó: "Tantos perigos passados, tantos duros trabalhos, no mar tanta tormenta e tantos anos, tantas fezes mijo diluído, na terra tanto berro e tanto engano, tanta ruim idade poluida, onde pode acolher-se um pobre humano, onde verá lonjura a curta vista?" (Sem grifo no original, p. 108). Em Camões, temos o seguinte: "No mar, tanta tormenta e tanto dano,/Tantas vezes a morte apercebida;/Na terra, tanta guerra, tanto engano,/Tanta necessidade aborrecida!/Onde pode acolher-se um fraco humano/Onde terá segura a curta vida?" (I, 106). O efeito paródico é acentuado, sobretudo, pela manutenção rigorosa, em Almeida Faria, do verso decassílabo e do esquema rímico camoneano (inclusive da rima interna terra/berro por terra/guerra): $a / b, a / b, a / b$, de tal maneira que se poderia visualizar cada unidade frásica de prosa como equivalente a cada verso de Camões, tornando a paródia assim mais eficaz. O ritmo mantém irônica epicidade, desmanchada quando se examina o valor semântico dos termos, que substituem alguns do original, provocando um deslocamento de sentido: "dano" é substituído por "anos"; "vezes a morte apercebida" por "fezes e mijo diluído"; "guerra" por "berro"; "tanta necessidade aborrecida" por "tanta ruim idade poluída"; "fraca" por "pobre" e "onde terá segura a curta vida" por "onde verá lonjura a curta vista". O presente criticado, em função do pretérito, que é paralelisticamente retomado, caracteriza-se pela ausência de grandeza. Sua evocação é determinada pela degradação inerente ao nosso tempo, que aponta não para um destino de grandeza, entrevista, em Camões, no ideal guerreiro ou no destino trágico da morte. O que há, em nossa época, são os estragos causados pela poluição ("idade poluída"), tanto sonora ("berro"), quanto material ("mijo e fezes"). Já o último segmento chama a atenção por sublinhar não uma questão metafísica, como no 
modelo camoneano, mas a limitação do homem do presente, pois a sua "curta vista" impede-o de ver longe.

Camões e J. C. irmanam-se como sonhadores de lonjuras, mas se distanciam na capacidade de realizar um desiderato. No caso, o poeta seiscentista, além de grande aventureiro, cristalizou suas aspirações num poema épico que cantava não só a grandeza da pátria como também sua agonia. J.C., por seu turno, não deixa um poema e longe está de celebrar a grandeza da pátria, que não mais a tem e que, por isso mesmo, se encontra em franca decadência. Neste sentido, é preciso refletir também que essa questão de visão de mundo está ligada a uma questão de forma literária, que é indiretamente tratada por Almeida Faria. A existência da epopéia, enquanto gênero literário autônomo e com características próprias (o interesse pelo coletivo, a presença dos versos, o estilo grandiloquiente, etc.), como bem observou Lukács em A teoria do romance, está atrelada a uma cosmovisão que reflete um mundo fechado, dentro do qual há um herói perfeitamente inserido no contexto e de que ele é porta-voz. Assim entendida, a epopéia rigorosamente só teria cxistência válida nos tempos em que ainda não se processara a irremediável fissura entre o indivíduo e o meio, em que a individualidade ainda não se manifestava de modo pleno. Do ponto de vista de Lukács, portanto, a cpopéia pura só teria vez mesmo entre os gregos, nos tempos homéricos. Em sendo assim, mesmo Os Lusiadas constituiriam uma obra anacrônica. Camões, num tour de force magistral, escreve sua epopéia num tempo que comporta precariamente uma epopéia e, para tanto, é obrigado a um "truque" literário para driblar a morte de uma visão inocente do mundo, representada, por exemplo, pela existência dos deuses. Daí nasce seu projeto de imaginar um sincretismo religioso: os deuses, confinados ao mundo da retórica, meros ornatos, a que se refere a própria Tethys, no canto $\mathrm{X}$, convivem harmoniosamente com o Deus cristão, este sim o detentor de poder, a divindade real.

Se Camões se equilibra precariamente sobre o fio da navalha, os seus colegas épicos ou pretensamente épicos dos séculos XVII e XVIII põem os pés pelas mãos, já que tais épocas comportam menos ainda epopéias. Nos séculos $\mathrm{XIX}$ e XX então nem se fala, pois a epopéia, enquanto gênero literário, está definitivamente morta e enterrada. Parece, pois, que J.C., um Camões paródico, tem plena consciência disso. Pelo menos em três momentos da obra de Almeida Faria se nota a certeza de que os tempos são outros e, por conseguinte, o modo de representá-los é também diferente dos do passado. Assim, por exemplo, em Lusitânia, J.C. dá a entender que a história que narra é "cómico-marítima" ( $L$, p. 12), referindo-se parodicamente à História trágico-marítima, obra de autor anônimo, publicada em 1735-1736 em dois volumes, e que narra grandes episódios épicos, num tom trágico. A comicidade do relato de J.C. tem sua razão 
de ser porque os acontecimentos dos tempos modernos, em sua degradação, perderam a epicidade, a tragicidade e, por isso mesmo, são motivo de riso. Em Cavaleiro andante, Almeida Faria, ao parodiar Carlos Drummond de Andrade, dizendo "não serei eu o cronista de nenhuma epopéia, para epopéia temos 'Os Lusíadas"” (CA, p. 165) (referência ao verso do poema "Mãos dadas": "não serei o poeta de um mundo caduco"), reafirma esta consciência de J.C. quanto à impossibilidade de ele, como poeta, realizar o mesmo que Camões realizou no século XVI.

Mas onde se verifica de maneira mais evidente a diferença entre ambos é na paródia que J. C. faz de um conhecido soneto de Bocage, em que o poeta setecentista se compara a Camões: "Quão diferente acho teu fado e o meu, quando os cotejo: outra causa nos fez perdendo o Tejo, encontrar novos aires e desaires, e versos tão diversos escrevemos, os teus famosos e heróicos, a mim cabendo a voz da negativa epopéia; não te imito nos dons da natureza, nem as eras são de igual grandeza" ( $C A$, p. 33). Observe-se o texto de Bocage: "Camões, grande Camões, quão semelhante/Acho teu fado ao meu, quando os cotejo!/Igual causa nos fez perdendo o Tejo/Arrostar co'o sacrílego gigante:/Como tu, junto ao Ganges sussurrante,/De penúria cruel no horror me vejo;/Como tu, gostos vãos, que em vão desejo,/Também carpindo estou, saudoso amante:/Ludíbrio, como tu, da Sorte dura/Meu fim demanda ao Céu, pela certeza/De que só terei paz na sepultura:/Modelo meu tu és... Mas, ó tristeza!.../Se te imito nos transes da Ventura,/Não te imito nos dons da Natureza." Almeida Faria mantém em parte o decassílabo bocageano nas frases "quão diferente...", "outra causa...", "encontrar novos", "e versos tão diversos...", "não te imito..." e "nem as cras...". Além disso, procura manter alguns termos fundamentais do texto original ("fado", "cotejo", "Tejo", "imito", "dons da Natureza") e, de modo geral, o que talvez seja mais importante na glosa, mantém o tom lamentoso, declamatório de Bocage. $O$ efeito paródico, no plano formal, plenamente satisfatório, casa-se com o efeito paródico atingido no plano semântico. Como já se disse, a paródia investe na criação de um canto contrário, em oposição ao texto que lhe serviu de modelo: no caso aqui, o romancista, ao invés de acentuar as semelhanças entre J.C. e Camões, como acontece em parte entre o "eu-poético" de Bocage e o próprio Camões no soneto, acentua só as diferenças. Os fados entre ambos são diversos, diversas foram as causas que os obrigaram a perder o Tejo. A única equivalência entre ambos reside na declaração de humildade que fecha tanto o poema de Bocage quanto a invocação de J.C. Contudo, há um detalhe a mais que serve para explicar a paródia: na comparação entre Camões e a personagem, ressaita a idéia de que os tempos são diferentes; o presente é despido de grandeza, o que implica que os versos 
do jovem pretendente a poeta não possam ser "heróicos" e que ele se veja obrigado a compor uma "negativa epopéia".

Em Cortes, a imagem dessa nova epopéia que J.C. perpetra, paralela à de Camōes, mas em tudo oposta a ela, surge de maneira muito clara quando Almeida Faria glosa os versos introdutórios de Os Lusíadas: "Ó vós ovas marinhas, pois criado tendes em J.C. um novo engenho ardente, dai-lhe em breve gozo alto e sublimado em actos grandíloquos e potentes, já que haveis consentido que ele seja neonato sob o lustral signo do líquido, sémen suor sangue saliva. Reencontrado vivo sobre as águas, ó vós tágides ninfas, dai-lhe uma fúria larga e sonorosa e não de leve avena ou frauta frouxa, antes de tuba canora e belicosa que os peitos de Marta acenda e a cor ao rosto mude. Vós condutoras deste que caminha pelas ruidosas ruas, dai-lhe ímpar força em famoso trio de espeto e dois beques que a tusa tanto ajude, que se torne esta jornada memorável nos cronicōes dos grandes fodelhões por todo o vasto mundo" (p. 48). Camões: "E vós, Tágides minhas, pois criado/Tendes em mi um novo engenho ardente,/Se sempre, em verso humilde, celebrado/Foi de mi vosso rio alegremente,/Dai-me agora um som alto e sublimado,/Um estilo grandíloquo e corrente,/Por que de vossas águas Febo ordene/Que não tenham inveja às de Hipocrene./Dai-me ua fúria grande e sonorosa,/E não de agreste avena ou frauta ruda,/Mas de tuba canora e belicosa,/Que o peito acende e a cor ao gesto muda;/Dai-me igual canto aos feitos da famosa/Gente vossa, que a Marte tanto ajuda;/Que se espalhe e se cante no Universo,/Se tão sublime preço cabe em verso" (I, 4-5). O efeito parodístico é conseguido pela substituição do destino guerreiro de todo um povo pela performance individual e sexual de J.C. A musa inspiradora, as Tágides do original, cedem lugar às "ovas marinhas", clara alusão ao afrodisíaco que levará a personagem a ter "breve gozo alto e sublimado" (que substitui "novo engenho ardente"). Quanto ao estilo camoneano, anunciado no verso "um estilo grandíloquo e corrente", será substituído pelos "actos grandíloquos e potentes". 0 adjetivo "potente", que toma o lugar de "corrente", servirá para acentuar o caráter sexual da experiência do jovem e, ao mesmo tempo, para modificar o sentido de "engenho ardente", que também ganha uma conotação sexualizada. O merecimento por parte de Camões do engenho justifica-se pelo fato de ele ter celebrado (ou seja, cantado) o rio; já a personagem de Almeida Faria nasce sob o signo aquático, venusiano, o que implicará que as ninfas lhe dêem uma "fúria larga e sonora".

A "fúria" não mais guerreira, mas erótica, impõe outra escolha neste processo de substituição: se em Camões, o uso da "tuba canora e belicosa", em detrimento da "agreste avena ou frauta ruda", justificava-se pelo tom épico da epopéia, em Almeida Faria, ela se dá pela transformação dos instrumentos 
musicais em símbolos fálicos. Assim, a "leve avena ou frauta frouxa" corresponderão ao membro masculino em repouso, enquanto que a "tuba canora e belicosa" corresponde ao pênis potencializado, a ponto de acender os "peitos de Marta" e de lhe mudar "a cor ao rosto". Ainda é importante assinalar a substituição de Marte, deus da guerra, pela amada de J.C., Marta, como se se acentuasse aqui, mais uma vez, que à epopéia dos novos tempos repugnam os feitos guerreiros. Assim, o "canto" que Camões pede às Tágides cederá lugar à "força", representada pelo órgão sexual masculino iconizado ("famoso trio de espeto e dois beques"), ajudado não por Marte, mas pela "tusa" (o equivalente, em Portugal, ao "tesão"). Para fechar o texto, ao invés do canto que se espalhe pelo "universo", Almeida Faria deseja que "se torne esta jornada memorável nos cronicões dos grandes fodelhões de todo o mundo". Além do aspecto sexual, portanto, é possível ainda perceber, na visão do romancista, uma diminuição de perspectiva: o universo restringe-se agora ao espaço do mundo.

$\mathrm{Da}$ analogia que se estabelece entre Camões e J.C., podemos chegar às seguintes conclusões:

1. O paralelismo entre ambos só é possível enquanto se aceitar que os dois poetas têm como alvo repensar o próprio país;

2. O paralelismo também é possível enquanto também se aceitar que, apesar de idêntico o ponto de partida, a reflexão sobre a pátria, cabe ao primeiro realizar uma autêntica epopéia, enquanto que ao segundo, a "negativa epopéia";

3. A "negativa epopéia", realizada por J.C., o avesso de Os Lusíadas, é representada pelo canto fragmentário de suas cartas, reflexões, e que não mais tem a dimensão de totalidade presente no épico camoneano;

4. Em substituição ao espírito belicoso, guerreiro de Camões, Almeida Faria aponta para a disponibilidade amorosa de J.C.; daí a presença de Marta em lugar do deus da guerra Marte.

5. Contudo, a par dessas diferenças flagrantes entre ambos, pode-se dizer que J.C., mesmo às avessas, identifica-se a Camões. As diferenças entre ambos são evidentes porque também outros são os tempos: "as eras", como, afinal, escreve o próprio romancista, "não são de igual grandeza".

Se o parâmetro de J.C. é Camões, o de André é D. Sebastiāo. Também ele um Cavaleiro andante, "o teu marinheiro aéreo, o teu cavaleiro do mar, o teu vagante sem casa onde ficar", como J.C., persegue ideais utópicos: "em sonhos continuo a nadar, o mar nunca mais acaba, a noite custa a dissipar" ( $C A$, p. 56). A identificação entre ele e a personagem histórica dá-se porque André, como o Desejado, igualmente morre em África, sem contar que a própria personagem toma consciência de certos detalhes temporais que o aproximam do lendário rei: "É curioso, conservarmos para a aviação a linguagem das 
viagens de barco, o que me lembra ter lido hoje nos jornais que neste mesmo dia, há quatrocentos anos, partiu D. Sebastião da foz do Tejo em direção ao suicídio que lhe seria fatal e ao país. Com certo frisson reparo que o Desejado era da minha idade e, supersticioso, desato a ver desastres. Faço votos para que a data não me seja agoirenta, tento não me deixar dominar por sugestões de calendário em que creio, involuntário" ( $C A$, p. 72).

Mas por que acontece a identificação tanto de J. C. quanto André com figuras exponenciais do passado português? Creio que isto se deve ao fenômeno da "inflação psíquica", que, como vimos, se refere aos casos em que o inconsciente individual de um homem é invadido pelos conteúdos do inconsciente coletivo, como se acontecesse um fenômeno típico de regressão. No romance de Almeida Faria, a "inflação psíquica" reveste-se de um sentido duplamente simbólico. De um lado, representa um salto abrangente, no sentido de mostrar que a saga da família emblematiza a saga de Portugal, ou, em outras palavras, o intuito do autor não é só o de mostrar destinos individualizados e, sim, coletivos, como se pode confirmar pelas palavras de André, em Cavaleiro andante: "Durante as minhas insônias crepitantes, penso que não me pertenço, sou não eu mas um povo inteiro perdido de si, confusamente à procura de não sabe que saída" ( $C A$, p. 105). De outro lado, representa também o fenômeno da identificação com arquétipos, através de um verdadeiro "eterno retorno", como se as personagens buscassem incessantemente o novo que as anima e que lhes dá vida, mas acabassem por sempre repetir velhos gestos, aprisionados num destino circular e sem saída. Não é à toa que André reflita em seu périplo o périplo do Desejado: deixando Portugal, irá morrer em terras de África. Ainda entre os dois, desenham-se laços estreitos, no que diz respeito a uma luta inglória contra o destino: D. Sebastião almeja reerguer o Império, expandir a Fé, cumprindo os sonhos de toda uma raça, cantados principalmente por Camões, em Os Lusíadas; André também, de certa forma, tenta reerguer seu pequeno império, o clã familiar, caído em desgraça depois da morte do patriarca. Viaja ao Brasil, para ver se faz fortuna, descobre que tem câncer e vai morrer em África, sem realizar nada do que pretendia.

$\mathrm{O}$ aprisionamento das personagens de Almeida Faria num círculo vicioso, que as impede de assumir os sonhos na totalidade, deve-se principalmente à onipresença do Pai. André e J.C. buscam romper com estruturas arcaicas, sonham com o novo, em seus périplos de cavaleiros andantes, contudo, à revelia deles, a sombra paterna os persegue. André, por ser o primogênito, sofrerá mais profundamente esta influência do Pai, ao ter que se sacrificar pelo bem estar do clã, ao ter que dedicar a vida à manutenção dos familiares. Contudo, J.C. não escapa também desse destino, em que pese a sua vontade em contrário. Ao 
deixar a casa, em A paixão, procura fugir da dominação paterna, dos valores que isso representa (o interesse pelo material, a prática da usura, o machismo egoísta, o patriarcalismo, o gosto do passado e de estruturas arcaicas) e, ao mesmo tempo, entregar-se, em Lisboa, ao gozo da plena disponibilidade, como se pode ver em Cortes, quando a personagem se põe a escrever prosa, um privilegiado modo de se escapar do utilitarismo: "A prosa, escrita na praia, perante os pires poentes sobre o mar, era má mas parecia-lhe dado o inédito prazer de escrevinhar, ludicamente, para si, entregue a essa 'finalidade sem fim', inexplicável, que hoje mesmo só pode compreender dificilmente" $(C, \mathrm{p} .16)$. Essa disponibilidade, essa busca do princípio do prazer, aumentará mais ainda quando, depois de rocambolescos fatos, ele será raptado junto com Marta e terminará aportando em Veneza. A escolha dessa cidade por Almeida Faria não é nada gratuita, já que ela representará o mundo da Beleza agonizante, um artificioso espaço, milagrosamente conservado, distante do mundo dos interesses e do utilitarismo: "fundar um sítio onde o reino da beleza, longamente sonhado e desejado e quase conseguido numa Veneza perdida" ( $C A$, p. 148). De certa maneira, será possível dizer que Almeida Faria parodia aqui Morte em Veneza de Thomas Mann. J.C. é um Aschenbach degradado, no sentido de que, inconscientemente, busca toda a beleza, toda a disponibilidade que não pode encontrar em Portugal. Mas, enquanto o aristocrata alemão morre pela beleza emblematizada no andrógino Tadzio, J.C. obriga-se a regressar à terra natal, levado pela consciência de um dever.

A disponibilidade, o princípio do prazer, será, portanto, representado no romance pela figura de Marta, o avesso de Marte, o deus da guerra. Nascido sob signo venusiano, sob o signo aquático, J.C. ("um dia terás de psicanalisar a tua relação com a água, com o mar", diz-lhe Marta, $C A$, p. 188) deveria viver a experiência erótica em plenitude e que é em tudo similar à estética, já que ambas não visam a um fim utilitário, já que ambas têm um fim em si mesmas. É Marta o Tadzio feminino, a anima de J.C., que lhe apontará o caminho dessa redenção artística. A anima, como se sabe, é o arquétipo do feminino no homem e que aponta para as pulsões poéticas, para tudo o que é criativo. Desse modo se explicam as glosas e comentários que J.C. faz dos ideais estéticos de Baumgarten. Para o filósofo setecentista, "enquanto na lógica o elemento sensível é mero meio para chegar a um fim, na estética este elemento é um fim em si" e "o fim da estética é a perfeição do conhecimento enquanto tal" (p. 124). A estética, parente do amor desinteressado, tem um "fim em si" e não visa, ao contrário da lógica, a um fim além de si. Marta, mais disponível que J. C. e menos comprometida com um clã, abraçará esse ideal supremo, utópico, ao se recusar a retornar a Portugal. Confinada aos limites de Veneza, tem, segundo 
J. C., um "estatuto esteticista" ( $C A$, p. 144) que a predispõe a viver em disponibilidade, sem lar, sem pátria e a criticar em J.C. o instinto lusíada do sacrifício, que o impede de viver o presente e o prazer: "Nessa lucidez incluo o conselho tantas vezes repetido de deixares tudo para vires ter comigo. Ninguém te agradece sacrifícios que de aqui a alguns anos hão-de parecer ridículos" ( $C A$, p. 110). Acontece que, ainda ao ver dela, J.C. se mostra "vencido pelo império da necessidade" ( $C A$, p. 133), no instante em que, premido pelo dever filial, deixa-a sozinha em Veneza e regressa a Portugal. Aliás, o próprio J.C. tem consciência do seu "aprisionamento" a uma forma de ser que, em parte, anula a sua busca do novo: "Falta muito ainda, se é que chega, o dia em que seremos nós mesmos, sem saudades do estúpido passado nem receio de arriscar no diferente. Por enquanto imitamos mal, e dói este espetáculo. Entretanto eu sacrifiquei o presente ao que os filósofos chamam 'administração racional da temporalidade', tornei-me ausência de mim mesmo a fim de defender valores alheios [...] Por gozador e donjuanesco que tenha tentado ser, não fui capaz, não sei viver $e$, ao encontrar contigo uma vaga possibilidade disso, logo consegui descobrir desculpas, complexos de dever a fim de fugir a sete pés" ( $C A$, p. 69-70). Chamam a atenção no fragmento a perda da própria imagem, em função do passado, dos valores que lhe são alheios, o conseqüente medo do diferente e a incapacidade de se viver com a disponibilidade com que Marta the acena de Veneza. Como André, esmagado pela onipotência da figura paterna, J. C. também se sacrifica ao deus Dever, ao deus do coletivo, como se pode ver na seguinte passagem, em que ele compara seu destino comprometido ao destino livre da amada: "Enquanto tu segues o princípio do prazer com desprezo pelo princípio da realidade, eu ando enganado em éticas nem sequer a Nicômano, bons sentimentos altruístas, sentimentalismos de sacrifício ao coletivo ainda que restrito da família, coisa que dantes dava direito a prêmios beatos e hoje acho piegas e barato" ( $C A$, p. 15).

Frente a esta impossibilidade de as personagens assumirem o novo, de "cortarem" definitivamente com o passado, de viverem o lúdico, o prazer, que posição o escritor Almeida Faria assume? Evidentemente (e felizmente), não é ele o vulgar moralista que aponte caminhos ou soluções ou que busque, em nome de uma ideologia, um caminho redentor para os entes que criou. Seu romance é uma epopéia degradada e/ou "negativa", epopéia do desencanto que reflete, de maneira muito lúcida, sobre o fenômeno do desengano do mundo moderno, sobre o beco sem saída em que se encontra Portugal. Apesar disso, no entanto, Almeida Faria acaba por apontar para uma saída puramente lúdica, para uma apologia do prazer e do erotismo, metáfora do estético, em seu último (até aqui) e parodístico romance, $O$ conquistador, que, de maneira emblemática, fecha 
paradoxalmente a demanda, ao abri-la, cantando a disponibilidade de seu anti-herói, que revisita talvez o mito mais caro da História portuguesa, que é D. Sebastião. Como se sabe, a figura do rei, devido a seu desaparecimento, no fim do século XVI, tornou-se um verdadeiro mito e, com a promessa de seu retorno ominoso, veio assombrando/animando o imaginário do povo português, já há alguns séculos, prometendo-lhe a tão almejada redenção ou mesmo reacendendo as esperanças de recuperar a grandeza perdida.

Almeida Faria, neste romance, promove parodisticamente o retorno desta figura emblemática, em 19 de janeiro (data de nascimento de el-rei D. Sebastião), numa praia do Cabo da Roca. Somente que o Sebastião do presente surge na praia "num ovo enorme, com a cabeça, as pernas e os braços de fora" $(C O$, p. 11), o que serve para lhe acentuar a ascendência venusiana, aquática (semelhante em tudo à de J.C.), e que já o predispõe para a prática do amor, como, aliás, o seu horóscopo, mais tarde, perpetrado por Helena, o atesta. Também é de se chamar a atenção a sua parecença física com o Encoberto: "Nessas reuniões surgia sempre o tema das semelhanças entre o Rei e eu: os olhos amendoados, os cabelos alourados, a cara oval, o beiço belfo dos descendentes de Carlos V, os dedos delicados, o tronco curto, desproporcionado em relação aos membros compridos de mais" ( $C O$, p. 71). Mas as semelhanças param aí: se D. Sebastião tinha "soberano horror ao comércio carnal" e manifestava "pelo belo sexo uma aversão extraordinária", obrigando-se, numa absurda compensação, a fazer imperar Marte sobre Vênus e a lançar-se a uma aventura doida, a uma "absurda batalha contra os árabes, em pleno deserto, no mês de agosto, sob um sol de quarenta graus", a uma "derrota ominosa", o Sebastião do presente propõe-se a seguir caminho inverso. Movido por "uma ambígua atração pelo desconhecido, e o gosto do risco", procurará suprir em tudo o que o Outro falhou, ou seja, nunca gramando guerreiros, detestando-os, procurará substituir a aventura bélica pela amorosa, dispondo-se a ser o "cavaleiro do amor". Daí que busque viver em disponibilidade, como se poderá observar em sua vida vivida ao sabor de aventuras, sem que se ligue necessariamente a um projeto definitivo. Em outras palavras, o Sebastião do presente pretende se entregar a "um apostolado laico", a "uma campanha contra a frustração, a tristeza e o desespero nas femininas fileiras", cumprindo o que D. Sebastião não fez. Ora, essa disponibilidade do herói é similar à tão decantada disponibilidade aventada por Marta, sobretudo, em Cavaleiro andante e similar mesmo à disponibilidade estética, já que a personagem vive o amor pelo amor em si, não visando, por exemplo, ao casamento, à procriação. $O$ culto de Eros tem, assim, o condão de apontar, emblematicamente, para um caminho aberto a todas as disponibilidades, subvertendo a fixação pelo passado, a consciência 
burguesa do dever e dos sa-crifícios cristãos, tão presentes no imaginário português e responsáveis pela criação de um destino atávico, que aprisiona o homem, impedindo-o de abraçar os sonhos com o Desconhecido.

\title{
RESUMO
}

Neste ensaio, trataremos da obra do romancista português Almeida Faria, da perspectiva da paródia, procurando demonstrar que, em seus romances, o autor dialoga com escritores da tradição literária portuguesa e da tradição universal, com vistas a formular uma crítica ao Portugal do presente. Trabalhando com o conceito de intertextualidade, pretendemos mostrar que suas personagens, ao reatualizarem determinados ritos, imitam, de modo inconsciente, procedimentos arcaicos, que os levam a um processo crescente de fuga e alienação. paródia.

Palavras-chave: Almeida Faria, romance português contemporâneo, mito,

\begin{abstract}
This essay deals with the literary works of the Portuguese writer, Almeida Faria, mainly with the parody. We tried to demonstrate that, in his novels, he dialogues with Portuguese writers of the past and with foreign authors, looking for a critical view of contemporary Portugal. Working with the concept of intertextuality, we intended to show that his characters run away from the reality when they imitate the procedure of theirs ancestors.
\end{abstract}

Keywords: Almeida Faria, contemporary Portuguese novel, myth, parody. 
GOMES, A. C. Sob o signo de Eros

\section{REFERÊNCIAS}

De Almeida Faria:

FARIA, Almeida. Rumor branco. 2. ed. Lisboa: Portugália, 1970. . A paixão. 3. ed. Lisboa: Editorial Estampa, 1976. . Cortes. Lisboa: D. Quixote/Nova Fronteira, 1978. Lusitânia. São Paulo: Difel, 1986. . Cavaleiro andante. Rio de Janeiro, 1987. . O conquistador. Rio de Janeiro: Rocco, 1993.

Sobre Almeida Faria:

MACHADO, Álvaro Manuel. A novelistica portuguesa contemporânea. Lisboa: Bertrand, 1984.

OLIVEIRA, Cristina Robalo Cordeiro. Almeida Faria, um itinerário. Colóquio/Letras, 69 , set. 1982.

SEIXO, Maria Alzira. A palavra do romance. Lisboa: Horizonte, 1968.

Várias:

ELIADE, Mircea. Mito e realidade. São Paulo: Perspectiva, 1970. Aspectos do mito. Lisboa: Edições 70, 1963. Tratado de história das religiões. Lisboa: Cosmo, 1970.

FRIEDRICH, Hugo. Estrutura da lírica moderna. São Paulo: Duas Cidades, 1978. GIDDENS, Anthony. As conseqüências da modernidade. Oeiras: Celta, 1996. HUTCHEON, Linda. Uma teoria da paródia. Lisboa: Edições 70, 1989.

JAMESON, Frederic. O pós-modernismo e a sociedade de consumo. In: KAPLAN, E. Ann (Org.) O mal-estar no pós-modernismo. Rio de Janeiro: Zahar, 1993.

JUNG, Carl Gustav. Métamorphoses de l'âme et ses symboles. Gêneve: Lib. de l'Université, 1967. . O eu e o inconsciente. Petrópolis: Vozes, 1979.

LUKÁCS, Georg. A teoria do romance. Porto: Porto Editorial, [s.d.]. MOISÉS, Massaud. Dicionário de termos literários. 3. ed. São Paulo: Cultrix, 1983. SANT' ANNA, Afonso Romano de. Paráfrase \& Cia. São Paulo: Ática, 1991. 